\title{
Longitudinal MRI study in schizophrenia patients and their healthy siblings
}

Rachel G. H. Brans, Neeltje E. M. van Haren, G. Caroline M. van Baal, Wouter G. Staal,

Hugo G. Schnack, René S. Kahn and Hilleke E. Hulshoff Pol

\section{Summary}

To investigate whether genetic and/or disease-related factors are involved in progressive structural brain changes in schizophrenia, magnetic resonance imaging scans with a 5-year scan interval were acquired in patients, their same-gender siblings and matched healthy controls.

Structural equation modelling was applied to assess disease and familial effects. Whole brain and cerebral grey matter volumes decreased excessively in patients compared with their siblings and the controls, suggesting that the progressive brain loss in schizophrenia may be related to the disease process.

\section{Declaration of interest}

None. Funding detailed in Acknowledgements.
Structural brain abnormalities have been reported consistently in patients with schizophrenia, ${ }^{1}$ with less pronounced abnormalities in first-degree relatives of patients. ${ }^{2}$ Thus, the volumetric differences may be related in part to the genetic risk of developing the disease. ${ }^{3}$ At least part of the morphological brain changes in schizophrenia are progressive over the course of the illness, ${ }^{4,5}$ but it is not known for certain whether they are mediated by genetic or disease-related factors.

\section{Methods}

Participants were recruited from the sibling-pair cohort and control sample ${ }^{6,7}$ at the University Medical Center Utrecht. At baseline, 16 patients with schizophrenia ( 12 male, 4 female), 18 same-gender siblings (14 male, 4 female) and 43 healthy controls (29 male, 14 female) matched for age, gender and parental education participated. Eleven patients ( 7 male, 4 female), 11 siblings ( 8 male, 3 female) and 33 controls ( 22 male, 11 female) completed the follow-up after 5 years $($ mean $=5.02$ years; s.d. $=0.39)$. Not all sibling-pairs were complete at follow-up; a total of 7 sibling-pairs were scanned twice. At baseline, mean age of the patients, siblings and controls was 40.9 years (s.d.=8.8), 41.2 years $($ s.d.=8.8) and 40.2 years (s.d. $=8.2$ ) respectively. Mean duration of illness in the patients was 19.6 years (s.d.=11.5). The follow-up sample was representative of the baseline sample in that groups did not differ in mean age, handedness, participants' and parental education, and duration of illness.

All individuals underwent extensive psychiatric assessment procedures using the Comprehensive Assessment of Symptoms and History ${ }^{8}$ at baseline and follow-up. Patients met DSM-IV criteria for schizophrenia and all siblings were healthy. Siblings were at least 8 years older than the age the affected sibling developed the first symptoms of schizophrenia; thus, they would be very unlikely to develop schizophrenia in the future. Outcome was assessed using the Global Assessment of Functioning, ${ }^{9}$ the Positive and Negative Syndrome Scale ${ }^{10}$ and the Camberwell Assessment of Need. ${ }^{11}$ Participants with a major medical or neurological illness, IQ below 80, previous electroconvulsive therapy, or history of substance dependence were excluded.

A table from the Dutch National Health Service ${ }^{12}$ was used to calculate the cumulative dosage of antipsychotics during the 5year scan interval and to derive haloperidol equivalents (HAL equiv.). During the scan interval, six patients were exclusively on atypical antipsychotics (including clozapine) and two on typical. Two patients switched between typical and atypical antipsychotics; for one patient reliable information on medication was absent. Mean cumulative antipsychotic medication during the scan interval was 14345.4 HAL equiv. (s.d. $=7984$ ). None of the siblings used antipsychotics. In all, $46 \%$ of patients (5 of 11 ), $18 \%$ of siblings (2/11) and $36 \%$ of controls (12/33) were smokers. All participants gave written informed consent. The study was approved by the medical ethics committee for research in humans (METC) of the University Medical Center Utrecht.

Magnetic resonance imaging (MRI) brain scans were acquired on a Philips NT (Best, The Netherlands) scanner operating at 1.5 $\mathrm{T}$ for all participants. A $3 \mathrm{D}$ fast field echo and a $T_{2}$-weighted dual echo-turbo spin echo were acquired. Protocol details and the imaging process are described elsewhere. ${ }^{7}$ Volumes of intracranium, whole brain, cerebral grey and white matter, lateral and third ventricular volumes, and cerebellum were measured.

Mixed model analysis was implemented using Structural Equation Modeling with Mx software for Windows (www.vcu.

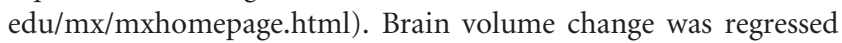
on intracranial volume, gender, age, disease (patients $v$. siblings and controls) and familial background (patients and siblings $v$. controls). Relatedness in the sibling-pairs was accounted for in the covariance structure by allowing dependencies between the residuals in the regression analyses. Effects of disease and familial background were tested by comparing the likelihoods of nested models ( -2 log-likelihood), which is chi-squared distributed; $\chi^{2}>3.84$ ( 1 d.f.) indicates a significant difference at $\alpha=0.05$, and depicts that the discarded effect (e.g. disease effect) cannot be left out of the model without seriously reducing the goodness of fit. Using the full model, estimates (including 95\% CIs) were obtained that indicated an increase or decrease of the dependent variable (brain volume change) in patients or in siblings.

\section{Results}

Over time, whole brain volume decreased excessively in patients $(-12.6 \mathrm{ml})$ compared with siblings $(+7.3 \mathrm{ml})$ and controls $(-2.3 \mathrm{ml})$ (Table 1). A greater decrease in cerebral grey matter volume was observed in patients $(-24.9 \mathrm{ml})$ than in siblings $(-9.8 \mathrm{ml})$ or controls $(-16.8 \mathrm{ml})$. Moreover, patients showed less prominent increases in cerebral white matter volume $(+5.3 \mathrm{ml})$ than siblings $(+12.9 \mathrm{ml})$ or controls $(+12.5 \mathrm{ml})$. Changes in grey and white matter volumes do not add up to changes in total brain volume, because grey/white matter was limited to the cerebrum (i.e. whole brain excluding cerebellum and brain-stem). 


\begin{tabular}{|c|c|c|c|c|c|c|c|c|c|c|}
\hline \multirow[b]{2}{*}{ Brain area } & \multicolumn{3}{|c|}{$\begin{array}{c}\text { Brain volumes at baseline, } \\
\text { ml: mean (s.d.) }\end{array}$} & \multicolumn{3}{|c|}{$\begin{array}{l}\text { Percentage change per year } \\
\text { per group, mean (s.d.) }\end{array}$} & \multicolumn{2}{|c|}{$\begin{array}{l}\text { Disease effects, } \\
\% \text { change/year }\end{array}$} & \multicolumn{2}{|l|}{$\begin{array}{l}\text { Familial effects, } \\
\% \text { change/year }\end{array}$} \\
\hline & Patients & Siblings & Controls & Patients & Siblings & Controls & Estimates $(95 \% \mathrm{Cl})$ & $\chi^{2}$ & Estimates $(95 \% \mathrm{Cl})$ & $\chi^{2}$ \\
\hline Whole brain & $\begin{array}{l}1226.0 \\
(154.4)\end{array}$ & $\begin{array}{l}1267.9 \\
(115.1)\end{array}$ & $\begin{array}{l}1264.8 \\
(109.7)\end{array}$ & $\begin{array}{l}-0.20 \\
(0.38)\end{array}$ & $\begin{array}{l}0.15 \\
(0.40)\end{array}$ & $\begin{array}{l}-0.04 \\
(0.41)\end{array}$ & $\begin{array}{c}-0.33 \\
(-0.61 \text { to }-0.06)\end{array}$ & $5.18^{*}$ & $\begin{array}{c}0.17 \\
(-0.15 \text { to } 0.49)\end{array}$ & 1.17 \\
\hline Cerebral grey matter ${ }^{\mathrm{b}}$ & $\begin{array}{l}599.8 \\
(78.5)\end{array}$ & $\begin{array}{l}640.7 \\
(71.0)\end{array}$ & $\begin{array}{l}636.5 \\
(65.1)\end{array}$ & $\begin{array}{l}-0.84 \\
(1.09)\end{array}$ & $\begin{array}{l}-0.18 \\
(1.00)\end{array}$ & $\begin{array}{l}-0.54 \\
(0.65)\end{array}$ & $\begin{array}{c}-0.70 \\
(-1.35 \text { to }-0.02)\end{array}$ & $3.97^{*}$ & $\begin{array}{c}0.40 \\
(-0.29 \text { to } 1.11)\end{array}$ & 1.39 \\
\hline Cerebral white matter $^{\mathrm{b}}$ & $\begin{array}{l}468.7 \\
(79.7)\end{array}$ & $\begin{array}{l}473.9 \\
(51.2)\end{array}$ & $\begin{array}{l}474.8 \\
(56.0)\end{array}$ & $\begin{array}{c}0.30 \\
(1.19)\end{array}$ & $\begin{array}{l}0.51 \\
(0.69)\end{array}$ & $\begin{array}{l}0.59 \\
(0.90)\end{array}$ & $\begin{array}{c}-0.36 \\
(-2.54 \text { to }-0.00)\end{array}$ & $3.89 *$ & $\begin{array}{c}-0.03 \\
(-0.50 \text { to } 0.44)\end{array}$ & 0.02 \\
\hline Cerebellum & $\begin{array}{l}144.2 \\
(19.9)\end{array}$ & $\begin{array}{l}140.5 \\
(14.6)\end{array}$ & $\begin{array}{c}140 \\
(10.9)\end{array}$ & $\begin{array}{l}0.28 \\
(0.37)\end{array}$ & $\begin{array}{l}0.52 \\
(0.54)\end{array}$ & $\begin{array}{c}0.19 \\
(0.55)\end{array}$ & $\begin{array}{c}-0.23 \\
(-0.63 \text { to } 0.17)\end{array}$ & 1.34 & $\begin{array}{c}0.33 \\
(-0.08 \text { to } 0.73)\end{array}$ & 2.63 \\
\hline Lateral ventricles & $\begin{array}{l}29.15 \\
(22.50)\end{array}$ & $\begin{array}{l}14.33 \\
(5.73)\end{array}$ & $\begin{array}{l}15.57 \\
(7.68)\end{array}$ & $\begin{array}{c}2.32 \\
(3.38)\end{array}$ & $\begin{array}{c}1.13 \\
(1.67)\end{array}$ & $\begin{array}{l}1.80 \\
(2.16)\end{array}$ & $\begin{array}{c}0.75 \\
(-2.18 \text { to } 3.23)\end{array}$ & 0.32 & $\begin{array}{c}-0.80 \\
(-1.68 \text { to } 0.09)\end{array}$ & 3.09 \\
\hline Third ventricles & $\begin{array}{c}1.65 \\
(1.13)\end{array}$ & $\begin{array}{l}1.15 \\
(0.62)\end{array}$ & $\begin{array}{l}0.89 \\
(0.41)\end{array}$ & $\begin{array}{c}2.70 \\
(4.35)\end{array}$ & $\begin{array}{l}-0.29 \\
(5.01)\end{array}$ & $\begin{array}{l}0.86 \\
(5.73)\end{array}$ & $\begin{array}{c}2.56 \\
(-2.61 \text { to } 7.14)\end{array}$ & 0.64 & $\begin{array}{c}-1.38 \\
(-4.56 \text { to } 1.87)\end{array}$ & 0.91 \\
\hline $\begin{array}{l}\text { a. Sample: patients with } \\
\text { indicates an increase (pos } \\
\text { b. Grey matter and white } \\
\text { * Significant differences at }\end{array}$ & $\begin{array}{l}\text { volum } \\
4 ; P<C\end{array}$ & $\begin{array}{l}\text { iblir } \\
\text { eas } \\
\text { o pa }\end{array}$ & $\begin{array}{l}\text { and } \\
\text { en esti } \\
\text { re mis }\end{array}$ & $\begin{array}{l}\text { controls } \\
f \text { the } d \epsilon\end{array}$ & The $e$ & $\begin{array}{l}\text { re co } \\
\text { ents }\end{array}$ & $\begin{array}{l}\text { for intracranial vol } \\
\text { lings compared wit }\end{array}$ & $\begin{array}{l}\text { e, age al } \\
\text { ontrols. }\end{array}$ & & \\
\hline
\end{tabular}

No associations were found between clinical variables and brain volume changes, except that a larger dose of atypical medication (including clozapine) during the scan interval was positively correlated with less progressive decrease in cerebral grey matter volume $(r=0.85 ; P=0.03)$.

When comparing patients and siblings as a group with the controls, no familial effects were found in any of the brain volume changes over time.

\section{Discussion}

The progressive decreases over time in whole brain and cerebral grey matter volume and less prominent increases in white matter observed in schizophrenia patients but not in siblings may represent a (disease-related) non-genetic risk factor for the disease. Our finding of progressive decrease over time is consistent with those of other longitudinal studies in schizophrenia. ${ }^{4,5}$ The findings in siblings are consistent with the normalisation of cortical thickness by the age of 20 in siblings of patients with childhood-onset schizophrenia. ${ }^{13}$

To our knowledge, this is the first longitudinal MRI study in chronically ill patients with schizophrenia and their healthy siblings. Siblings share on average $50 \%$ of their genes. The siblings in this study were all healthy and beyond the age of risk for schizophrenia. Possibly, the disease alleles of schizophrenia-related genes may be underrepresented in these siblings.

This study has several limitations. First, the number of participants was small and genetic factors involved in progressive brain changes in schizophrenia may not have been elucidated owing to a limited statistical power. Second, it is likely that at least some of the disease alleles of schizophrenia-related genes are not present in this sample of healthy siblings of patients. Our findings have to be considered preliminary and more final conclusions await follow-up studies in monozygotic and dizygotic twin-pairs discordant for schizophrenia that are currently underway.

Rachel G. H. Brans, MS, Neeltje E. M. van Haren, PhD, G. Caroline M. van Baal $\mathrm{PhD}$, Wouter G. Staal, PhD, MD, Hugo G. Schnack, PhD, René S. Kahn, PhD, MD, Hilleke E. Hulshoff Pol, PhD, Rudolf Magnus Institute of Neuroscience, University Medical Center Utrecht, The Netherlands

Correspondence: Rachel G.H. Brans, Rudolf Magnus Institute of Neuroscience Department of Psychiatry, University Medical Center Utrecht, A01.126,

Heidelberglaan 100, 3584 CX Utrecht, The Netherlands. Email: R.Brans@azu.nl

First received 11 Jun 2007, final revision 7 May 2008, accepted 12 Jun 2008

\section{Acknowledgements}

This research was supported in part by Grant No. 908-02-123 (HEHP) from the Netherlands Organization for Health Research and Development ZonMw.

\section{References}

1 Wright IC, Rabe-Hesketh S, Woodruff PW, David AS, Murray RM, Bullmore ET. Meta-analysis of regional brain volumes in schizophrenia. Am J Psychiatry 2000; 157: 16-25.

2 Boos HB, Aleman A, Cahn W, Hulshoff Pol HE, Kahn RS. Brain volumes in relatives of patients with schizophrenia: a meta-analysis. Arch Gen Psychiatry 2007; 64: 297-304.

3 Hulshoff Pol HE, Brans RGH, van Haren NEM, Schnack HG, Langen M, Baaré WF, van Oel CJ, Kahn RS. Gray and white matter volume abnormalities in monozygotic and same-gender dizygotic twins discordant for schizophrenia. Biol Psychiatry 2004; 55: 126-30.

4 van Haren NEM, Hulshoff Pol HE, Schnack HG, Cahn W, Brans RGH, Carati I, Rais M, Kahn RS. Progressive brain volume loss in schizophrenia over the course of the illness: evidence of maturational abnormalities in early adulthood. Biol Psychiatry 2008; 26: 106-13.

5 Pantelis C, Yücel M, Wood SJ, Velakoulis D, Sun, D, Berger G, Stuart GW Yung A, Phillips L, McGorry PD. Structural brain imaging evidence for multiple pathological processes at different stages of brain development in schizophrenia. Schizophr Bull 2005; 31: 672-96.

6 Staal WG, Hulshoff Pol HE, Schnack HG, Hoogendoorn ML, Jellema K, Kahn RS. Structural brain abnormalities in patients with schizophrenia and their healthy siblings. Am J Psychiatry 2000; 157: 416-21.

7 Hulshoff Pol HE, Schnack HG, Bertens MG, van Haren NEM, van der Tweel I, Staal WG, Baaré WF, Kahn RS. Volume changes in gray matter in patients with schizophrenia. Am J Psychiatry 2002; 159: 244-50.

8 Andreasen NC, Flaum M, Arndt S. The Comprehensive Assessment of Symptoms and History (CASH). An instrument for assessing diagnosis and psychopathology. Arch Gen Psychiatry 1992; 49: 615-23.

9 Hall RC. Global assessment of functioning. A modified scale. Psychosomatics 1995; 36: $267-75$.

10 Kay SR, Fiszbein A, Opler LA. (1987) The positive and negative syndrome scale (PANSS) for schizophrenia. Schizophr Bull 1987; 13: 261-7.

11 Phelan M, Slade M, Thornicroft G, Dunn G, Holloway F, Wykes T, Strathdee G, Loftus L, McCrone P, Hayward P. The Camberwell Assessment of Need: the validity and reliability of an instrument to assess the needs of people with severe mental illness. Br J Psychiatry 1995; 167: 589-95.

12 Commissie Farmaceutische Hulp van het College voor Zorgverzekeringen Farmacotherapeutisch Kompas [in Dutch]. Amstelveen, The Netherlands, 2002.

13 Gogtay N, Greenstein D, Lenane M, Clasen L, Sharp W, Gochman P, Butler P, Evans A, Rapoport J. Cortical brain development in nonpsychotic siblings of patients with childhood-onset schizophrenia. Arch Gen Psychiatry 2007; 64: 772-80. 